\title{
Medical equipment-based procedures in cosmetic technologies
}

\author{
Elżbieta Wenerska-Wojtaszek
}

Vincent Pol University in Lublin, Poland

In modern world, procedures associated with beauty maintenance or restoration are one of the most profitable services. Many cosmetic procedures are based on the action of active substances, natural or produced by pharmaceutical companies (like medicines). The results of such procedures can be enhanced by various physical phenomena, as each form of energy generates biological effects. The effects of cosmetic procedures depend on numerous factors, including the kind and intensity of energy, time and the areas involved as well as the kinds of tissues that are affected.

Modern cosmetological procedures are based on various physical phenomena. The most common ones include electromagnetic radiation, ultrasounds, various frequency currents, changes in pressure or temperature. Until recently, these phenomena have been used separately. At present, in order to obtain better effects, the combination of two of them is most frequently applied, e.g. laser light and radiofrequency (RF) or intensive pulsating light (IPL) and RF. Such combinations improve the effectiveness of procedures albeit increase the risk of adverse side effects.

Thanks to continuous research and technical advances, miniaturisation and market competitiveness, the combined procedures are becoming the future of beauty salons.

The aim of the present paper was to discuss the selected procedures based on medical devices used for treating the most common cosmetic defects; moreover, the biophysical processes occurring in the affected tissues were described.

Key words: cosmetology, biophysics, cosmetic procedures based on medical devices, combined procedures

\section{Introduction}

One of the creative activities of man is science, which allows us to get to know and understand the surrounding world and its processes as well as ourselves and relations among the individual environmental elements. Natural sciences are empiric fields, which study nature as well as its processes and phenomena using increasingly complex techniques and devices [1].

Natural sciences include physics, biology chemistry, and many other areas. All these fields overlap; therefore, it is difficult to separate biology and chemistry or physics and biology. They are strictly interconnected in terms of research subjects and methods used to study them, which results in numerous interdisciplinary sciences, such as biochemistry, biophysics or medicine, medical aesthetology or cosmetology. In recent years, the practical applications of science have been of the utmost importance. Considering the current trend of staying young, healthy and slim, it is not surprising that aesthetics-related disciplines, e.g. aesthetic medicine or cosmetology, have been rapidly developing. This development is mainly associated with the prolongation of lifespan and the period of old age. Therefore, the knowledge of the phenomena connected with the process of ageing is insufficient; prevention and even reversal of the changes resulting from the passage of time are essential. The modern market of aesthetic and cosmetic procedures does not rely exclusively on therapeutic effects of various active substances but 
also on the impact of physical factors. And that is the area where biophysics and cosmetology meet.

\section{Use of physical phenomena in cosmetic procedures}

Biophysics, associated with biology and physics, explains the structure, changes and functioning of organisms using physical laws. Moreover, it deals with the effects of physical factors on biological structures and their functions, which is directly applied in cosmetology. The major objective of cosmetology is not only to study and describe but also to care, restore and enhance the physical attractiveness of the human body. To achieve this goal, various non-invasive procedures are used, some of which are based on physical phenomena [2].

Cosmetic procedures commonly use the physical phenomena such as electromagnetic radiation, ultrasounds, currents of various frequencies as well as changes in pressure and temperature. Any form of energy induces biological consequences that depend on various factors, e.g. the type of energy, its intensity, time of exposure and kinds of the tissues affected. Until recently, the phenomena mentioned above were used separately, thus the procedures applied were based on the action of one of them. Currently, better effects are achieved when two phenomena are used simultaneously, e.g. laser light and RF or IPL and RF. Such combinations improve the effectiveness of procedures albeit increase the risk of adverse side effects. The line between therapeutic and adverse effects is particularly thin when highpower devices are applied. Although this line can be determined using biological knowledge, due to an abundance of issues connected with many borderline natural fields, the knowledge and its practical applications, especially among cosmetology beginners, are not sufficient and biophysics itself is often underestimated.

\section{Chromophores, proteins and biological membranes versus cosmetic procedures}

\subsection{Chromatophores}

The human body of an adult contains $62 \%$ of water, $40 \%$ of which is in the intracellular space and only $22 \%$ in the extracellular space. Moreover, water is one of the major skin chromophores. It is capable of absorbing the energy of light waves, e.g. laser beams, and convert it into heat energy, responsible for proper therapeutic action. Water and water-rich tissues absorb well the radiation of the wavelength below $500 \mathrm{~nm}$ and above $1200 \mathrm{~nm}$ [3].

Another chromatophore is melanin commonly present in the skin and hair. Melanins are dyes which are produced during melanogenesis. This process is activated by skin exposure to UV radiation. Melanins are predominantly synthesised by UVB radiation and oxidised by UVA radiation [4]. Biosynthesis of melanin in humans takes place in the melanocytes and retinal pigmented epithelium. The number of mature melanocytes in the skin depends on the race. Its distribution varies in the individual skin parts with the highest number found in the head and forearm - about $2000 / \mathrm{mm}^{2}$ of skin surface [5]. Melanins are polymers that give colours but mainly protect the cells against the harmful effects of UV radiation; furthermore, they eliminate free radicals. Melanin is capable of dispersing and absorbing UV radiation as well as of converting the absorbed energy of electromagnetic radiation into thermal energy. The maximum absorption ability is observed in the short-wave part of UV radiation and gradually decreases towards the visible light [6]. Thanks to the above ability of melanin, the heat generated can be used in beauty salons for stimulation or destruction of chemical molecules or biological structures.

Still another chromatophore is haemoglobin $\mathrm{Hb}$ present in the erythrocytes. $\mathrm{Hb}$ is a protein 
composed of the proaesthetic part - haeme and a simple protein-globin. A single $\mathrm{Hb}$ molecule contains four protein subunits, each of them with one haeme group. The $\mathrm{Fe}^{2+}$ ion present in it is essential as it enables binding of oxygen molecules. Transport of respiratory gases, mainly oxygen and carbon dioxide (yet to a lesser degree), is the major function of haemoglobin. Similar to melanin mentioned earlier, haemoglobinis a chromatophore, i.e. a molecule capable of absorbing radiation energy of a defined wavelength. The oxygenated form of Hb, oxyhaemoglobin, is of bright red colour and shows two absorption maxima in the range of yellow and green spectrum (578 $\mathrm{nm}$ and $540 \mathrm{~nm}$ ). Deoxygenated haemoblobin is red-violet and its adsorption peak is spectrometrically observed at the wavelength of $565 \mathrm{~nm}$ [7]. In cosmetology, this property can be used to destroy the haemoglobincontaining structures, such as telangiectasias.

\subsection{Collagen and elastin}

Collagen and elastin are proteins occurring in the connective tissue; they are the main components of ligaments or skin responsible for its tonicity, elasticity and resilience. Both proteins have a specific composition of amino acids with glycine and proline constituting a substantial part plus hydroxyproline in the case of collagen. Moreover, the spatial structure of these proteins is distinctive. The basic collagen macromolecule is composed of three left-handed polypeptide chains, which interweave around the common axis forming the conformation of superhelix. The resultant tropocollagen, stabilised by covalent and hydrogen bonds, is essential for the properties of the molecules of this protein. Moreover, non-helical fragments (telopeptides) are also involved, which are present at the ends of collagen macromolecules or incorporate into the structure of superhelix [8]. Furthermore, the interactions between the polypeptide chain and water have been demonstrated to participate in the stabilisation of superhelix [9].

Elastin is a fibral protein produced by hydrophobic fibroblasts into the intercellular space where it forms the support for the morphotic components of the connective tissue, mediated by collagen and other substances. Its transverse bonds arrange in fibres or membranes of elastin, which is associated with its elasticity and stretching. When relaxed, elastin forms an irregular spiral susceptible to stretching. Therefore, the cells and tissues rich in elastin return to their normal shape after stretching or compression [10].

With ageing, the skin looses its properties, its elasticity decreases and slight wrinkles or creases start to appear. The physiological process of skin ageing is strictly associated with the loss of elastin and conversion of soluble collagen into its insoluble form [10]. The above results from increasingly low activity of fibroblasts producing collagen and elastin, enhanced activity of enzymes breaking down these proteins and changes in the spatial structure of collagen, in which the number of network bonds increases leading to stiffening of its structure. Moreover, the negative effects of environmental factors are important, e.g. $\mathrm{pH}$ changes, UV radiation or higher temperatures $[11,12]$.

Knowing the chemical composition of collagen and elastin as well as the processes of their biosynthesis, we can use physical factors to stimulate the fibroblasts for synthesis of proteins or changes in their spatial structure.

\subsection{Biological membranes}

A living organism, being a biological system, is composed of cells. Each of them is surrounded by the biological membrane, which acts as a border enabling the maintenance of cell integrity by maintaining its characteristic chemical composition, which is markedly different from 
the structure of the environment. Although the chemical composition of membranes varies, their major functions and structure are universal. Lipid compounds constitute about 60 $\%$ of membranes; the remaining $40 \%$ are proteins. Moreover, the membranes can contain covalently bound saccharides, forming glycolipids and glycoproteins.

In cosmetology, selective permeability of the biological membranes is of utmost importance, which means that intercompartmental transport of molecules is limited. Furthermore, they are involved in intercompartmental transfer of chemical substances and energy. Transmembranous transport of substances can be passive, in response to the stimuli and without the energy expenditure, or active that requires the expenditure of metabolic energy and occurs against the electrochemical potential gradient.

Passive transport can occur via simple diffusion conditioned only by the differences of concentrations between the membrane layers; carbon dioxide, urea, and some drugs are transported passively. In complex diffusion, some other thermodynamic stimuli are also of importance, e.g. a chemical potential gradient or pressure gradient. Additionally, the carriers capable of binding substrates on one side of the membrane and of transferring them across them are required for facilitated diffusion [13].

Beside the membrane structure, the factors that determine its permeability are the physicochemical properties of molecules composing it, mainly their electric properties. Therefore, apolar molecules diffuse easier through the membrane compared to polar hydrophilic molecules, which is consistent with the rule that similar things dissolve in similar ones.

Transport of active substances in the dermal cells additionally lengthens the multilayered structure of the stratum corneum, which can be considered as many lipid layers. Non-polarity of this layer favours the permeation of non-polar and non-ionic substances of lyophillic nature and low molecular weight. The efficiency of transmembranous transport can be regulated by structural changes of the lipid double layer itself, as in a defined temperature it changes from the strictly packed gel to the liquid-crystalline phase, which is looser and less arranged. An increase in temperature causes the formation of free areas that can be filled with water, which substantially facilitates the permeation of polar molecules through the membranes [14]. The use of various physical factors can modify the permeability of biological membranes, which can be applied in cosmetology to enhance the penetration of active substances into the skin. The physical methods used in cosmetology that increase transdermal penetration include ionophoresis using the effects of direct current, sonophoresis in which ultrasounds are used or electroporation based on high-voltage alternating current. The biological effect of such procedures is to increase the tissue temperature, which results in the altered membranous state of matter and in formation of canals and pores facilitating the penetration of active substances [15].

\section{Selected cosmetic issues and medical equipment-based procedures}

In order to use the physical phenomena in beauty salons, specialist equipment is required, which has been designed only recently. Thanks to continuous advances in science and technology, newer and more advanced devices have been launched. The physical phenomena generated by these devices are mainly based on:

$\checkmark$ flow of heat energy thermal energy,

$\checkmark$ flow of low and high frequency currents,

$\checkmark$ emission of light radiation,

$\checkmark$ emission of ultraviolet (UV) radiation, 
$\checkmark$ emission of infrared(IR) radiation,

$\checkmark$ emission of ultra- and infrasounds,

$\checkmark$ pressure changes.

Various types of electromagnetic radiation are likely to be most commonly used in cosmetology, including:

$\checkmark$ intensive pulsating light (IPL);

$\checkmark$ lasers of various strength wavelength;

$\checkmark$ light-emitting diodes (LED);

$\checkmark$ UV radiation;

$\checkmark$ IR radiation.

The physical phenomena used in cosmetology include:

$\checkmark$ mechanical waves (ultrasounds and infrasounds);

$\checkmark$ currents of various frequencies;

$\checkmark$ pressure changes;

$\checkmark$ temperature changes.

Noteworthy, each form of energy has biological action; however, the therapeutic effect can be achieved only using this part of energy that is absorbed by appropriate structures. Subsequently, this energy is transformed into another form, e.g. a quantum of electromagnetic radiation is transformed into thermal energy. As a result, the biological action is associated with an increase in tissue temperature yet the outcome depends on the type and intensity of the energy applied.

The effects obtained thanks to procedures with medical devices can be classified into several groups, some of them stimulating and others destroying the biological structures.

\subsection{Improvement of skin structure}

The most widely used procedures performed in beauty salons are those aimed at improving the skin structure and restoring its elasticity and resilience. Lasers of low and medium strength, $\mathrm{RF}$, infrared radiation or LED light as well as ultrasounds are applied for such purposes. The essential biophysical process occurring during the procedures is the conversion of electromagnetic radiation or energy generated during the current flow into thermal energy and local warming of collagen and elastin fibres. This shortens the fibres even by 1.3 of their length, which produces the effect of lifting. An increase of temperature above $40^{\circ} \mathrm{C}$ results in the loss of properties of individual proteins; at $60-70^{\circ} \mathrm{C}$, type I collagen denaturises. The thermal damage to collagen activates the fibroblasts to increased production of not only collagen but also elastin and hyaluronic acid, which additionally improves the level of skin moisture [16].

Interestingly, the procedures with low temperatures also shrink the collagen fibres, thus can be used in texture-improving and smoothing procedures [17].

Likewise, in the procedures with ultrasounds the mechanical wave energy is transformed into heat, which increases the production of hyaluronic acid, collagen and elastin [18].

\subsection{Stimulation of metabolism and cell processes}

By increasing the temperature of the area affected, the biochemical processes in the tissues can be strengthened. The procedures with lasers, IPL, LED, RF, IR, ultrasounds or currents of various frequencies have stimulating effects, increase the permeability of biological membranes, influence blood vessels and accelerate cell metabolism. Thermal energy produced in the tissues dilates the blood vessels, which increases the blood flow; thus, the supply of oxygen, nutrients and regulators improves. Thanks to this, the biochemical processes are accelerated and the metabolites produced do not accumulate in the cells but are systematically removed. Thus, an increased capillary flow supports the regeneration of the tissues subjected to various physical factors $[16,18]$.

Ionophoresis or cryoelectrophoresis is likely to increase the permeability of biological 
membranes, which improves the penetration of active substances. The substances can get directly to the cells where they can also be involved in simulation and regeneration of biological processes. However, it should be remembered that not only stimulating but also potentially toxic or dangerous substances are likely to penetrate the inside of the skin.

Phototherapy with light emitting diode (LED) is based on the light of a defined wavelength. Such procedures slow down skin ageing by activating the cell regeneration, enhancing cell metabolism, or reducing the number of free radicals. Red light of 650-730 nm stimulates fibroblasts to synthesise collagen and elastin as well as glycoproteins and glycosamines. Green light (525-550 nm) is used to reduce wrinkles and accelerate the epithelial regeneration. Moreover, yellow light (560-590 nm) stimulates the lymphatic and nervous systems. LED phototherapy can be combined with other physical methods, e.g. cryotherapy. The simultaneous action of light energy and low temperatures enables multifaceted improvement of the skin condition and increases the absorption of active substances used in cosmetic preparations applied onto the skin. Furthermore, local cooling of the skin quickly constricts and relaxes the capillary vessels, which improves the oxygenation of dermal cells. As a result, functioning of dermal cells improves.

The stimulating procedures with laser light can be combined with the magnetic field action. The mechanism of simultaneous use of magnetic and laser effects on the skin improves metabolism. The magnetic field determines the direction of the tissue optic axis, affects diffraction and dispersion of light. The magnetic field acts as a specific polariser directing the molecular dipoles, which deepens the permeation of light into the skin. Therefore, the penetration of low-energy laser radiation quanta is deeper and the therapeutic effects can be observed in the deeper layers [19].

\subsection{Removal of scars, discolourations and teleangiectasias}

Some cosmetic problems, e.g. discolourations, scars, telangiectasias, tattoos or excessive hair growth require the procedures that destroy the macromolecules or biological structures. The most common procedures are based on laser light, IPL or ultrasounds. Natural chromophores, e.g. hemoglobin or melanin, absorb the energy of radiation of a defined wavelength, thanks to which the surrounding structures are not damaged. Thermal effects are observed only at the place of energy absorption and can vary depending on the tissue temperature provided.

Photoepilation is an example of the use of laser light to remove excessive hair. The energy of radiation is absorbed by melanin present in the hair papilla. The resultant elevated temperature thermally damages the papilla and simultaneously destroys its blood vessels. One of the innovative devices applied to remove unnecessary hair is a diode laser emitting the light of $808 \mathrm{~nm}$, which directly reaches the hair follicle without damaging the epithelial cells. The effects observed are long lasting and more quickly visible, as compared to ILP epilation [20]. Likewise, the removal of hyperpigmentation is based on selective photothermolysis.

During the removal of vascular lesions, the light energy is absorbed by haemoglobin and transformed into heat, which causes protein coagulation, destruction of vascular walls and water evaporation. High-power lasers have photo-ablative effects. In such procedures, water molecules are a chromatophore and the external epithelial layers are removed by coagulation, volume explosion, or vapolarisation. Moreover, unnecessary hair or discolourations can also be removed using ultrasounds.

One of the procedures based on two physical factors is electro-optical synergy (ELOS) using 
RF currents and light. The skin electric properties depend on its temperature; the warmer the skin, the lower the electrical resistance. The RF current more easily eaches the regions previously warmed with light. Thanks to synergic use of light energy an RF currents, the penetration is deep, thus, deeply located changes can be removed while the risk of damage to the surrounding tissues is minimised. Depending of the light length, the ELOS device can be used for various cosmetic procedures, e.g. hair epilation, removal of pigment and vascular changes, photorejuvenation and fibroblast stimulation [21].

\subsection{Silhouette modelling}

Special cases of destructive procedures are those that are aimed at modelling the silhouette. They are mainly targeted at the adipocytes and the expected effect is their permanent destruction or shrinkage. In such cases, the physical phenomena associated with electromagnetic radiation are less effective; the procedures based on mechanical actions or low temperatures are superior. In many instances, RF currents, ultrasounds, pressure changes or cryotherapy are used. Numerous procedures based on low temperatures have recently been introduced. Freezing of the adipose tissue has been demonstrated to destroy the adipocytes and release fatty acids stored in them. The optimal temperature for cryolipolysis ranges from $+5^{\circ} \mathrm{C}$ to $-15^{\circ} \mathrm{C}$. To optimise the outcomes, the procedure combined with other methods is applied, e.g. ultrasound cavitation, which results in the formation of cavitating bubbles that implode generating the change in pressure and the shock wave [22].

Moreover, laser procedures are applied to model the silhouette, i.e. lipolysis based on the effects of high-intensity diode lasers. The length of laser light is selected in such a way as to selectively affect the adipocytes and destroy them. In cases of transdermal reduction of the adipose tissue, cold lasers are used, which shrink the adipocytes and simultaneously release free triglycerides from them. In such procedures, the laser light of 635 to $680 \mathrm{~nm}$ is applied. The biological action of cold lasers is based on the stimulation of mitochondria, an increase in the level of lipase that breaks down triglycerides into fatty acids and glycerol, and an increase in permeability of the adipocyte membrane, thus easier secretion of waste products into the intercellular space. Moreover, the flow of blood and lymph is increased, which accelerates the transport of fatty acids into the liver. To enhance the effect, accelerate the metabolism of triglycerides and improve the skin condition, ultrasounds, lymphatic drainage and RF procedures are co-applied [22].

A novel method is a complex cryoshaping based on the action of low temperatures, lymphatic drainage and suitably chosen cosmetic products. The method not only models the silhouette but also improves the skin appearance, reduces swellings and improves the body immunity [17].

\section{Summary}

Thanks to continuous research, better technical capacities, miniaturisation and competitionrelated needs, combined procedures are the future of beauty salons.

The combination of two or more different physical phenomena in one procedure enables us to achieve various effects during one session. In order to optimise the effects, the phenomena are selected as to affect a particular problem multifacetedly. However, high costs of devices and necessary trainings of the personnel are the major issues as it translates into costs of procedures hence their availability.

Furthermore, thelong-term effects are notknown, both positive and negative. It should be considered that increased permeability of membranes for active substances increases the risk of penetration of toxic substances, which is likely to injure cell structures or impair cell metabolism. It is noteworthy to mention 
the study results proving that high energy visible light (HEVL) can also be equally harmful as accumulative action of UV radiation. HEVL is the $\sim 400-500$ $\mathrm{nm}$ radiation of high frequency. It penetrates the subcutaneous tissue and blood vessels and generates free radicals, which favours photo-ageing and carcinogenesis. Surprisingly, an argon laser emitting the light of 458 - $514.5 \mathrm{~nm}$ is still commonly used in beauty salons [23].

Therefore, to minimise the risk of complications and optimise the effects of cosmetic procedures based on physical phenomena, it is essential to learn about and optimise the biophysical processes occurring in the tissues, cells and molecules in the structures subjected to cosmetic procedures.

\section{References}

1. Majkut J., O teorii i praktyce badań naukowych: (z myślą o nauczycielu akademickim). Toruń; Press: 1992.

2. Śpiewak R., Kosmetologia. Dermatopedia, 2013; 2 (pl):002

3. Mańkowska A., Laseroterapia wysokoenergetyczna w wybranych problemach dermatologicznych i kosmetycznych - doświadczenia własne. Rozprawa doktorska, Uniwersytet Medyczny im. Karola Marcinkowskiego. Poznań; Press: 2010.

4. Wenerska-Wojtaszek E., Ocena wiedzy klientów solariów na temat wybranych zagadnień promieniowania nadfioletowego. Zeszyty Naukowe WSSP, Lublin, 2011; 13, 35-61

5. Brenner M., Hearing V.J., The protective role of melanin against UV damage in human skin. Photochem. Photo-biol., 2008; 84: 539-549

6. Rok J., Otręba M., Buszman E., Wrześniok D., Melanina - z melanocytu do keratynocytu, czyli jak przebiega transport melaniny w skórze. Ann. Acad. Med. Siles., 2012; 66, 1, 60-66

7. http://biofizyka.p.lodz.pl/cw8.pdf - dostęp 20.04.2018

8. Silver F.H., Christiansen D.L., Biomaterials Science and Biocompatibility. New York, Press: 1999; 9-26, 62-68

9. Banaś M., Pietrucha K., Typy i struktura białka kolagenowego. Zeszyty Naukowe PŁ, Łódź, 2009; 1058,73

10. Łubkowska B., Grobelna B., Maćkiewicz Z., Rola aminokwasów w białkach podporowych skóry. Pol J Cosmetol, 2011; 14(4): 217-223

11. Kucharz E. J., The collagens: biochemistry and pathophysiology. Berlin-New York; Press: 1992.

12. Żelaszczyk D., Waszkielewicz A., Marona H., Kolagen - struktura oraz zastosowanie w kosmetologii i medycynie estetycznej. Estetol Med Kosmetol; 2012; 2(1): 14-20

13. Kawiak J., Mirecka J., Warchoł J., Podstawy cytofizjologii. Warszawa; Press: 1998.

14. Cieślik-Boczula K., Gąsiorowski K., Jaszczyszyn A., Świątek P., Malinka W., Rola lamelarnych warstw lipidowych w procesie przenikania substancji przez skórę. Kosmet. Estet., 2013; 1(2): 19-22

15. Goliszewska A., Gromek M., Padlewska K., Kosmetologia pielęgnacyjna. Warszawa; Press: 2011.

16. Potargowicz E., Michalak K., Lasery w kosmetologii. Lecznicze właściwości laserów niskiej mocy i ich zastosowanie w kosmetologii. Pol J Cosmetol, 2003; 6(4): 241-245

17. Wilczyńska K., Niskie temperatury w medycynie i estetyce. Rozmowa z Arturem Warzocha. Kosmet. Estet, 2013; 2(2): 122-123

18. Goik U., Goik T., Załęska-Żyłka I., Zastosowanie ultradźwięków w kosmetyce i kosmetologii. Pol J Cosmetol, 2012; 15(3): 170-176

19. Kurkus B., Kulińnski W., Laseroterapia w medycynie fizykalnej. Balneologia Polska 2005; 3-4, 76-83

20. Gaczek A., Fotoepilacja laserowa. Na czym polega zjawisko fotoepilacji. Postępy Kosmetologii, 2011; 4(2): 271-293

21. http://syneron-candela.com - dostęp 20.04.2018

22. Bandachowicz D., Przegląd aparatury do likwidacji tkanki tłuszczowej. Kosmet. Estet., 2013; 3(2): 221223

23. Krzyżostan M.,Frakcjonowana melanina pierwszym składnikiem kosmetycznym chroniącym skórę przed światłem widzialnym o wysokiej energii. http://biotechnologia.pl/kosmetologia/artykuly dostęp 20.04.2014

\section{Elżbieta Wenerska-Wojtaszek}

Wyższa Szkoła Społeczno-Przyrodnicza

im. Wincentego Pola,

Wydział Nauk o Zdrowiu

ul. Choiny 2, 20-816 Lublin

e.wenerska@gmail.com 